\title{
Generasjoner imellom: Holdninger til familiens ansvar øst og vest i Europa
}

\author{
Katharina Herlofson, ${ }^{\star}$ Svein Olav Daatland \& Marijke Veenstra \\ Velferdsforskningsinstituttet NOVA, OsloMet - Storbyuniversitetet
}

\begin{abstract}
Between generations: Attitudes towards family responsibilities in the East and the West of Europe

The article addresses the strength and character of family responsibility norms in Eastern and Western Europe. The strength is measured by the level of support for filial and parental responsibilities (i.e., adult children's obligations towards older parents and vice-versa) and the character is indicated by the priority given to the older or the younger generation. For the analyses, we employ data from thirteen Eastern and Western European countries participating in the Generations and Gender Survey. In general, family norms are stronger in the East than in the West, but it is difficult to establish where to draw a dividing line. The contrast between the two extremes, Norway and Sweden in the north-west and Georgia in the south-east, is striking. The remaining countries line up quite close along the geographical diagonal (from Scandinavia to Georgia). The character of the norms is less clearly distributed - whereas almost all countries in Eastern Europe give priority to the older generation, the picture in the West is more mixed. The results partly confirm earlier conclusions about east-west differences in family responsibility norms, but adding more countries to the analyses has revealed a more complex and ambiguous picture than presented in previous studies.
\end{abstract}

Keywords: comparative studies, family norms, intergenerational relationships, welfare state

Bør voksne barn stille opp når foreldre får behov for hjelp? Har foreldre noe ansvar for sine barn etter at de har blitt myndige? Og finnes det noe skille mellom landene i det østlige og vestlige Europa når det gjelder denne type forpliktelser? Hvorvidt voksne barn har et moralsk ansvar overfor sine foreldre, har i lang tid vært et sentralt tema i internasjonal aldersforskning, ikke minst med bakgrunn i bekymringer om befolkningsaldring og familiens evne og vilje til å ta seg av den eldre generasjonen (Bengtson \& Putney, 2000; Pruchno \& Smyer, 2007). Foreldres ansvar for voksne barn har fått mindre oppmerksomhet da forpliktelser nedover i generasjonslinjen i hovedsak dreier seg om mindreårige barn (Blustein, 1997). Men selv om foreldrerollen endres over livsløpet, så slutter ikke nødvendigvis foreldre å føle

^Kontaktinformasjon: Katharina Herlofson, epost: kather@oslomet.no 
ansvar overfor sine døtre og sønner etter at myndighetsalderen er passert (Gutmann, 1987). I denne artikkelen belyser vi begge sider - både den yngre generasjonens forpliktelser overfor den eldre og omvendt, den eldre generasjonens ansvar overfor den yngre. Vi vil ta for oss både styrken og karakteren til slike forpliktelser. Styrken måles ved hvor sterk oppslutningen om familiens ansvar er i befolkningen, mens karakteren indikeres ved hvorvidt det er den eldre eller den yngre generasjonen som prioriteres. Vi er ute etter holdninger og ikke etter hva folk faktisk gjør eller ikke giør. Hvorvidt og i hvilken grad idealene etterleves, er altså ikke tema her, og følgelig er holdningene til personer med og uten foreldre eller barn like interessante for vår studie.

Tilgang til sammenliknbare data fra tretten europeiske land gjør det mulig å undersøke om det er systematiske kontraster mellom ulike geografiske områder av Europa i oppslutningen om familieforpliktelser. Spørsmålene vi stiller er følgende: Er det markante forskjeller i holdninger til familiens ansvar på tvers av ulike land i Europa? Og dernest, ser vi noe tydelig skille mellom landene i det østlige og vestlige Europa når det gjelder styrken og karakteren til denne type normer? Vi vil også undersøke om det er noen kjennetegn ved de ulike landene som kan bidra til å forklare befolkningens oppslutning om familieforpliktelser.

\section{Bakgrunn}

For mer enn femti år siden konkluderte John Hajnal (1965) at det gikk an å skille den europeiske familien $i$ en østlig og en vestlig variant på hver side av en geografisk akse som gikk fra St. Petersburg i nord til Trieste i sør. Øst for denne aksen, som senere har blitt omtalt som "Hajnal-linjen», var det vanlig med tidlige giftermål og storfamilier, mens det i vest var en større andel ugifte, alder ved inngåelse av ekteskap var høyere og fruktbarhet lavere. Peter Laslett (1983) la senere til en horisontal akse, som i tillegg delte den europeiske familien inn i en nordlig og en sørlig type. Den nord-vestlige familien, med England og Norden, hadde ifølge Laslett en tradisjon for kjernefamilier og et ideal om uavhengighet mellom generasjonene. I sør og øst derimot, sto flergenerasjonsfamilien vesentlig sterkere med høye andeler hushold bestående av to (eller flere) voksne generasjoner.

Det har vært vanligere å studere familierelasjoner i det vestlige Europa enn $\mathrm{i}$ det østlige, og fokus har særlig vært på kontraster mellom nord og sør. David Reher, som i utgangspunktet var negativ til ideen om at ulike deler av Europa har særegne familieidealtyper (Viazzo, 2010), publiserte en artikkel i 1998 der han tegnet et nokså tydelig nord-sør-skille. Konklusjonen hans var at familier i Nord-Europa er kjennetegnet av svake generasjonsbånd, mens relasjonene i sør fremstår som sterke. Indikatorene Reher bygget sin konklusjon på, var i hovedsak alder for å flytte hjemmefra og ytelse av omsorg til familiens gamle. Han viste her til mønstre med dype historiske røtter helt tilbake til senmiddelalderen. Mens det i nord fra langt tilbake var vanlig å forlate barndomshjemmet tidlig for å søke tjeneste andre steder (se Sogner \& Telste, 
2005, om norske tjenestejenter fra 1600-tallet og frem til andre verdenskrig), ble unge i Sør-Europa som regel boende hjemme til de giftet seg. Mange fortsatte dessuten å bo sammen med foreldre etter inngått ekteskap. I nord derimot, var det hele tiden en sterk tradisjon for separate hushold (Laslett, 1983; Gaunt, 1983). Ettersom mange - både unge og gamle - dermed ble uten tilstrekkelig støtte i sin familie, ble det i denne delen av Europa tidlig utviklet kollektive hjelpeformer. I nyere tid har disse blitt overtatt (og utvidet) av velferdsstaten, noe som har bidratt til å redusere individets avhengighet av familien ytterligere, herunder behovet for familieomsorg $\mathrm{i}$ alderdommen (Esping-Andersen, 1999).

Konklusjonen til Reher (1998) om at alder for å flytte hjemmefra er høyere og at omsorgsytelser er mer omfattende i sør enn i nord, kan langt på vei sies å ha blitt bekreftet i nyere studier. Det er stadig vekk slik at utflytting finner sted senere (Billari \& Liefbroer, 2010) og at gamle foreldre oftere bor sammen med voksne barn i sør enn i nord. Og bor de ikke sammen, så er den geografiske avstanden kortere, og de har hyppigere kontakt med hverandre (Hank, 2007; Calzada \& Brooks, 2013; Mönkediek \& Bras, 2014). Videre er ytelser av pleie til familiens gamle langt mer omfattende i sør (Brandt, Haberkern \& Szydlik, 2009; Verbakel, 2018), men det bør bemerkes at dersom praktisk hjelp inkluderes, blir nord-sør skillet mindre utpreget (Brandt, Haberkern \& Szydlik, 2009).

I de senere årene har det kommet flere studier som også inkluderer land i den østlige delen av Europa. Her har det blitt påpekt at det er store likheter mellom Østog Sør-Europa (Calzada \& Brooks, 2013; Castiglioni et al., 2016). For eksempel likner omfanget av flergenerasjonshushold i mange av landene i øst mer det søreuropeiske mønsteret enn det (nord-)vestlige, og tilsvarende har blitt rapportert for geografisk avstand (Iacovu \& Skew, 2011; Mönkediek \& Bras, 2014). Når det gjelder kontakt, ser det derimot ut til å være lite i det østlige Europa som minner om det tette mønsteret det har blitt rapportert om for landene i sør (Murphy, 2008; Mönkediek \& Bras, 2014). Hvilke dimensjoner ved familiebånd som studeres kan altså se ut til å ha betydning for det bildet vi får, et poeng som har blitt understreket av blant annet Dykstra (2018). Dette kan også illustreres for den affektive karakteren til familierelasjoner - følelsesmessig nærhet - som ikke ser ut til å følge noe entydig geografisk mønster (Daatland \& Lowenstein, 2005).

Det normative aspektet ved familien, som er tema for denne artikkelen, handler primært om i hvilken grad familiegenerasjoner bør ha et moralsk ansvar overfor hverandre og inkluderer både voksne barns ansvar for foreldre og foreldres forpliktelser overfor voksne barn (og barnebarn) (Bengtson \& Roberts, 1991). Det vanlige har vært å studere det førstnevnte, som på engelsk gjerne går under betegnelsen «filial responsibility». Temaet har særlig blitt belyst i studier fra USA (f.eks. Finley, Roberts \& Banahan, 1988; Lee, Peek \& Coward, 1998) og Asia (bl.a. Sung, 1990; Treas \& Wang, 1993). I den øst-asiatiske tradisjonen står "filial piety» (fra Konfucius) sentralt - barn skal hedre og ære sine foreldre, glede dem og ta vare på 
dem når de blir syke (Ikels, 2004). "Filial responsibility» er ikke like forpliktende og dreier seg oftest om voksne barns moralske ansvar for å ta seg av foreldre med behov for hjelp. Etter hvert har det kommet europeiske studier der også sammenlikninger på tvers av land står sentralt (Lowenstein \& Daatland, 2006; Daatland, Herlofson \& Lima, 2011; Mureşan \& Hărăguş, 2015; Marckmann, 2017). Ansvaret den andre veien - foreldres ansvar overfor voksne barn - har fått mindre oppmerksomhet (Herring, 2008). Hvorvidt det er den eldre eller den yngre generasjonen som prioriteres, har dermed heller ikke blitt belyst i særlig omfang i tidligere forskning (Marckmann, 2017).

Når det gjelder oppslutningen om voksne barns ansvar for eldre foreldre, tyder tidligere studier på at fordelingen følger en diagonal fra nordvest til sørøst der forpliktelsene blir sterkere desto lengre øst og sør en kommer (Daatland, Herlofson \& Lima, 2011; Mureşan \& Hărăguş, 2015). At det er store likheter mellom sør og øst i denne type normer, bekreftes av Castiglioni og kolleger (2016), samt Calzada og Brooks (2013). Et tilsvarende mønster har også blitt rapportert for ansvaret den andre veien - foreldres forpliktelser overfor voksne barn. Daatland og kolleger (2011) og Marckmann (2017) har sammenliknet holdninger til henholdsvis voksne barns og foreldres ansvar og konkludert at forpliktelsene oppover generasjonslinjen står relativt sterkere i det sentrale og østlige Europa, mens ansvaret nedover er tydeligere i vestlige og nordlige områder av kontinentet. Mønsteret i Sentral- og Øst- Europa kan i så måte se ut til å likne det øst-asiatiske der "filial piety» står vesentlig sterkere enn "parental piety» $(\mathrm{Li}, 2011)$. I de nordiske landene derimot, er det et tydelig fokus på barn og ansvaret nedover (Hagestad, 2003), noe som også har kommet frem i den europeiske verdiundersøkelsen. I Skandinavia var det flere som svarte at «foreldre må gjøre sitt beste for sine barn selv om det går på bekostning av eget velbefinnende» enn det var som mente at «barn må alltid elske og respektere sine foreldre». I land som Tyskland, Italia og Spania var det omvendt (van den Akker, Halman \& de Moor, 1993).

Styrken og karakteren til familienormer, og til familierelasjoner generelt, er neppe et resultat av geografien som sådan, selv om klima og natur kan ha bidratt til å forme boligmønstre og levemåter på ulike vis. Som nevnt over, legger Reher (1998) vekt på de dype historiske røttene. Både han og Höllinger og Haller (1990) trekker fram blant annet religion med protestantismens fokus på individet og katolisismens vektlegging av kollektivet (Greeley, 1989) som en viktig kilde til kontrastene i familiemønstre mellom nord og sør. Mer nærliggende hendelser kan også ha satt sine spor, så som de to verdenskrigene og jernteppet mellom vest og øst. Repressive kommunistregimer kan ha tvunget folk til å søke beskyttelse i familien, og da i en mer tradisjonell familieform som føltes trygg og til å stole på (Szydlik, 1996). På den andre siden er det også mulig at kommunistiske staters forsøk på å kontrollere individenes livsløp, og gjøre dem mer knyttet til arbeidsplassen enn til familien, kan ha bidratt til å splitte familiemedlemmer fra hverandre og dermed svekke båndene 
mellom generasjonene (Preoteasa, Vlasa \& Tufã, 2018; Rajkai, 2015; Szydlik, 1996). Ifølge Zimmer og kolleger overlevde imidlertid de historisk sterke familienormene den kommunistiske perioden i et land som Romania (Zimmer, Rada \& Stoica, 2014). Videre har en rekke forfattere vist til familiens økte betydning i flere østeuropeiske land etter kommunismens fall (Castiglioni et al., 2016; Ghodsee \& Bernardi, 2012; Rajkai, 2015; Zimmer, Rada \& Stoica, 2014). Her trekkes særlig inn individenes tiltakende avhengighet av familien, forårsaket blant annet av økonomiske vanskeligheter (Robila, 2004; Rajkai, 2015).

Resultater fra tidligere forskning om familierelasjoner viser til dels betydelige forskjeller mellom Øst- og Vest-Europa. Dette gjelder også for familieansvarsnormer, som fremstår som vesentlig sterkere i den østlige enn i den vestlige delen av kontinentet. Sistnevnte funn er basert på studier som inkluderte henholdsvis sju (Daatland, Herlofson \& Lima, 2011) og ni land (Mureşan \& Hărăguş, 2015). Spørsmålet er om det fortsatt er rimelig å snakke om et øst-vest-skille i holdninger til denne type forpliktelser eller om mønsteret blir mer sammensatt når vi utvider analysene til å omfatte sammenliknbare data fra tretten land: fem fra nord og vest i Europa (Norge, Sverige, Belgia, Tyskland og Frankrike) og åtte tidligere kommuniststater fra øst (Polen, Tsjekkia, Romania, Bulgaria, Estland, Litauen, Russland og Georgia).

\section{Data og mål for familieforpliktelser}

\section{Surveydata}

Analysene som presenteres i denne studien bygger på data fra den internasjonale surveyundersøkelsen til Generations and Gender Programme (GGP). Datainnsamlingen er så langt gjennomført i nitten land. Siden det ikke er noe krav til de enkelte deltakerlandene om å inkludere alle surveyspørsmålene, har noen av landene valgt å utelate enkelte bolker, som for eksempel spørsmål om familieforpliktelser. For tretten av landene er sammenliknbare data tilgjengelige for vårt formål (Norge, Sverige, Belgia, Tyskland, Frankrike, Tsjekkia, Polen, Estland, Litauen, Romania, Bulgaria, Russland og Georgia). Størrelsen på de landsrepresentative utvalgene varierer fra 7163 i Belgia til 19987 i Polen. Alt i alt besvarte rundt 135000 kvinner og menn i alderen 18 til 80 år spørsmålene om familieansvar. Samlet svarprosent er på nærmere 60 med ytterpunktene Belgia (42\%) og Romania (84 \%) (Fokkema et al., 2016).

Innsamlingen av data startet i 2004. Estland og Bulgaria var først ute, fulgt av Tyskland, Frankrike, Tsjekkia og Romania i 2005 og Litauen og Georgia i 2006. I Russland strakk innsamlingen seg over fire år - fra 2004 til 2008. I 2008-10 ble den gjennomført for Belgia og i 2010-11 for Polen. Sverige var sist ute med datainnsamling i 2012-13. Norges deltakelse var et samarbeid med den andre runden til Den norske studien av livsløp, aldring og generasjon (NorLAG) som ble gjennomført i 2007-08 (svarprosent $61 \%$ ) (Slagsvold et al., 2012). 


\section{Familieansvar}

Målet for familieforpliktelser som er brukt her består av til sammen seks spørsmål om familiens ansvar. Det dreier seg om ulike påstander som respondentene ble bedt om å si seg enig eller uenig i, hvorav fire (a-d) refererer til voksne barns ansvar, mens to (e-f) handler om foreldres forpliktelser. Påstandene er formulert generelt, både for å vise til kulturelle verdier mer enn til private omstendigheter og for å være like relevante for personer med og uten foreldre eller barn:

a. Voksne barn bør ta ansvar for å gi omsorg når foreldre trenger det

b. Voksne barn bør tilpasse jobb etter foreldres behov

c. Voksne barn bør gi økonomisk hjelp til foreldre med økonomiske vansker

d. Voksne barn bør ha foreldre boende hos seg når foreldre ikke kan ta vare på seg selv

e. Hvis voksne barn trenger hjelp bør foreldre tilpasse sitt liv for å hjelpe dem

f. Foreldre bør gi økonomisk hjelp til voksne barn som har økonomiske problemer

Svarene på spørsmålene ble gitt langs en femdelt skala fra «svært enig» til «svært uenig» (via "enig», «verken enig eller uenig», «uenig»). Disse har vi snudd og slått sammen til en indeks for familieansvar ved å summere svarene for de enkelte spørsmålene (der 0 = svært uenig, $1=$ uenig, $2=$ verken/eller, $3=$ enig og $4=$ svært enig) og deretter dele på antall ledd. Indeksen varierer dermed fra 0 til 4 . Cronbachs alpha for leddene i den anvendte indeksen varierer fra 0,68 i Frankrike til 0,79 i Sverige. I tillegg har vi delt indeksen $i$ to ved å følge samme framgangsmåte som for familieansvar generelt - en for voksne barns ansvar (a-d) og en for foreldres ansvar $(\mathrm{e}-\mathrm{f})$ - for å kunne sammenlikne oppslutningen om forpliktelser oppover og nedover generasjonslinjen. De to delindeksene måler litt ulike forhold, henholdsvis ansvaret overfor foreldre og overfor voksne barn, men de to korrelerer allikevel betydelig $(0,48)$.

\section{Kontekstuelle data}

Tabell 1 gir en oversikt over ulike kjennetegn ved deltakerlandene. Både her og i presentasjonen av funn har vi sortert landene geografisk så godt det har latt seg giøre. Vi har valgt å starte lengst nord og vest med Norge og Sverige, og ende opp lengst i sør-øst med Georgia. Som vi ser av bredde- og lengdegradene til deltakerlandenes hovedsteder, så er ikke rekkefølgen perfekt av den grunn at flere av landene, naturlig nok, ikke befinner seg langs den geografiske diagonalen. Frankrike og Belgia ligger lengst vest, Russland og Georgia lengst øst. Vi har plassert Estland og Latvia foran Romania og Bulgaria fordi de to sistnevnte landene befinner seg lengre øst (selv om hovedstaden i Bulgaria ligger vest for både Tallinn og Vilnius). Selv om land som Tsjekkia og Polen regner seg som del av det sentrale Europa, inkluderes de her i den østlige delen i og med deres tidligere tilhørighet til det kommunistiske Øst-Europa. De tretten landene skiller seg for øvrig fra hverandre når det gjelder både økonomi, 


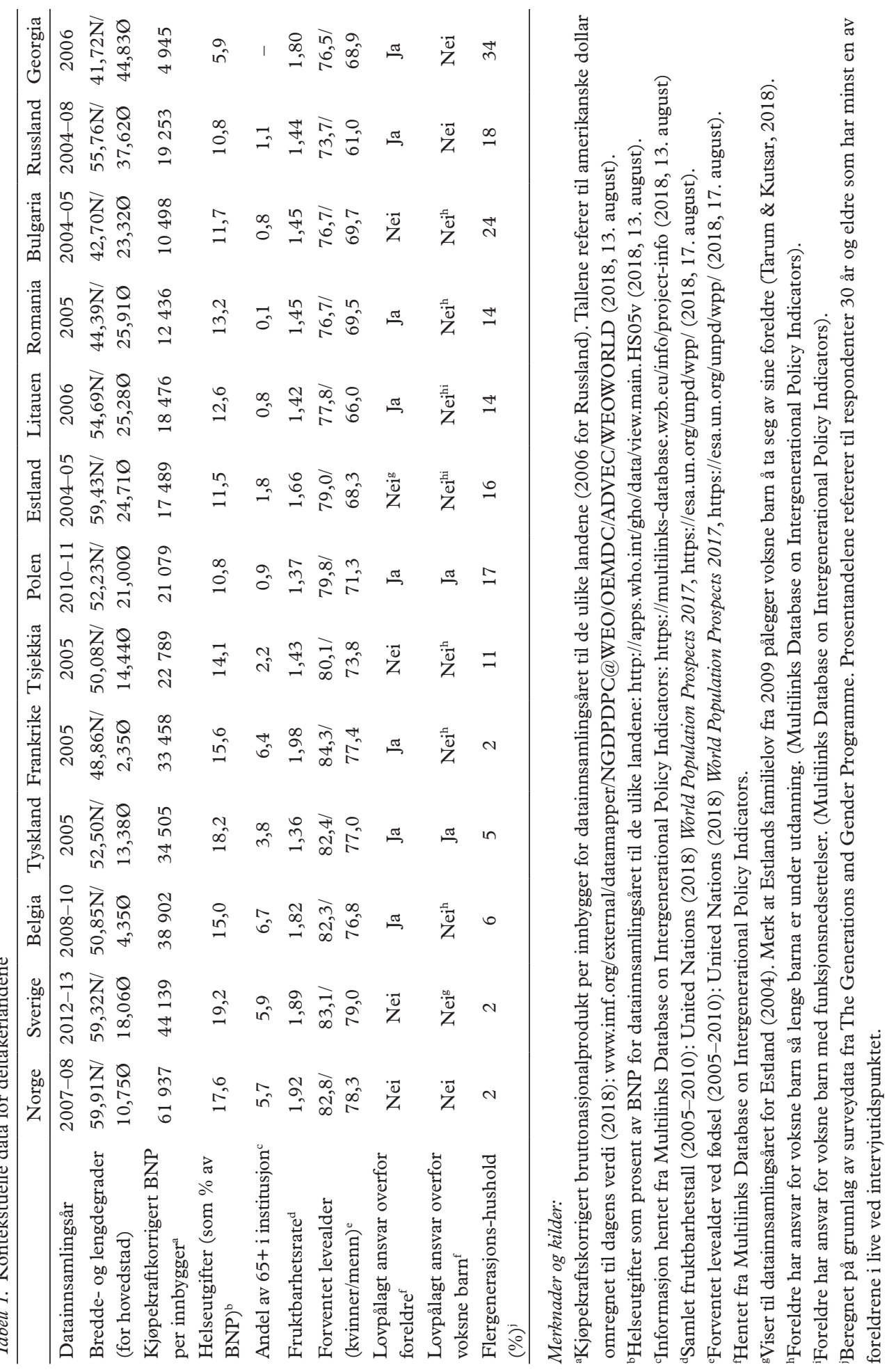


demografi, sosialpolitikk og lovgivning. Informasjonen i tabellen gjelder for datainnsamlingsåret (i den grad det har latt seg gjøre) for å kunne framstille landenes situasjon i den perioden data ble samlet inn.

Flere av indikatorene følger den (nord)vestlige til den (sør)østlige diagonalen. Både kjøpekraftskorrigert bruttonasjonalprodukt (BNP i PPP per innbygger), helseutgifter, institusjonsrater og levealder er høyest i vest (og nord) og blir - med få unntak - lavere jo lengre øst og sør vi kommer. Norge er det klart rikeste landet, med kjøpekraftskorrigert bruttonasjonalprodukt på mer enn 60000 amerikanske dollar per innbygger, som ikke er langt unna det dobbelte av Tyskland og Frankrike. Verdiene er enda lavere i de østlige landene og aller lavest i Georgia (4 945 USD). Merk at tallene referer til amerikanske dollar for datainnsamlingsåret til de ulike landene som så er omregnet til 2018 verdi (for komparasjonens skyld). De vestlige landene har også mer sjenerøse helsetjenester, målt ved helseutgiftenes andel av landenes bruttonasjonalprodukt. Eldreomsorgen er også bedre utviklet i vest om vi dømmer etter institusjonsratene. Mens andelen av befolkningen på 65 år og eldre som bor på institusjon varierer mellom 3,8 prosent (Tyskland) og 6,7 prosent (Belgia) i vest, så har de fleste landene i øst rater på under 1 prosent. Unntakene er Estland med 1,8 prosent og Tsjekkia med 2,2 prosent, som allikevel er lavere enn andelen for Tyskland. Den svært lave raten i Romania (0,1 \%) bekreftes av Zimmer og kolleger (2014). De beskriver hvordan offentlig eldreomsorg ble neglisjert av det kommunistiske styret og fortsatte å ha lav prioritet etter kommunismens fall til tross for $ø k t$ bevissthet rundt behovet for formelle omsorgstjenester. Sammen med Bulgaria skiller Romania seg fra flere av de andre landene i det østlige Europa med en mindre utviklet velferdsstat, noe som blant annet har blitt forklart med de to landenes svake økonomi over lang tid (Sotiropoulos, Neamtu \& Stovanova, 2003).

Videre ser vi at samlet fruktbarhetstall er høyere i vest enn i øst (med unntak av Tyskland), noe som står i motsetning til hva som var tilfellet tidligere ("Hajnallinjen»). Fram til midten av 1980-tallet var landene i det østlige Europa i stor grad kjennetegnet av en lav alder for ekteskapsinngåelser, en lav andel barnløse og en relativt høy fruktbarhet sammenliknet med hva som var tilfellet i mange av de vesteuropeiske landene. Etter 1990 falt fruktbarheten betydelig (Sobotka, 2011). Det er ulike oppfatninger av hva som kan forklare denne nedgangen, som Billingsley (2010) har kalt "the post-communism puzzle». Noen legger vekt på den økonomiske krisen, andre mener at det dreier seg om en utsettelse av fødsler, mens andre igjen hevder at det handler om den andre demografiske overgangen som har truffet øst senere enn vest (se bl.a. Sobotka, 2008). Billingsley (2010) bekrefter betydningen av den økonomiske utviklingen, men hevder at de to andre forklaringene også spiller inn, dog i ulik grad i de forskjellige landene.

Vi kan ellers notere oss at voksne barn i Norge og Sverige ikke lenger har noe lovpålagt ansvar for eldre foreldre. I Norge ble dette ansvaret overført til velferdsstaten i og med lov om sosial omsorg som ble innført midt på 1960-tallet. Foreldre i Norge har heller ikke noe juridisk ansvar overfor myndige barn. I Sverige fortsetter 
ansvaret så lenge barna er under utdanning. Skandinavia skiller seg fra de aller fleste landene i det vestlige og sørlige Europa når det gjelder familielovgivning. Det vanlige her er at foreldre og voksne barn er juridisk ansvarlige overfor hverandre (Saraceno \& Keck, 2008). Ser vi på landene i det østlige Europa derimot, er bildet annerledes. Mens de fleste landene har nedfelt i lovverket at voksne barn er ansvarlige for foreldre, så er det kun i Polen at ansvaret også går den andre veien.

Til sist har vi tatt med en indikator for flergenerasjonshushold, her målt ved andelen voksne barn $i$ alderen 30 år og eldre som bor sammen med foreldre. I følge data fra surveyundersøkelsen til Generations and Gender Programme, som gir sammenliknbare rater for samtlige land i utvalget, gjelder dette for en drøy tredjedel i Georgia, sammenliknet med kun 2 prosent i Norge, Sverige og Frankrike. Landet med den laveste andelen i den østlige delen av Europa erTsjekkia med 11 prosent - nesten dobbelt så høyt som andelen for Belgia (som ligger høyest blant de nord-vestlige landene vi har med her).

\section{Analytisk strategi}

Vi starter med deskriptive framstillinger av fordelinger når det gjelder oppslutningen om familiens ansvar i de ulike landene. Vi ser både på ansvaret samlet og på forpliktelser overfor henholdsvis foreldre og voksne barn for å kunne vurdere om det er den eldre eller den yngre generasjonen som har prioritet. For å undersøke om verdiene for de ulike landene skiller seg statistisk signifikant fra hverandre, gjør vi en variansanalyse (ANOVA). Deretter kjører vi flernivåanalyser (random intercept model), der individer (nivå 1) er gruppert innenfor land (nivå 2), for å få et inntrykk av hvor mye av variasjonen i oppslutningen om familiens ansvar som er knyttet til land og hvor mye som er knyttet til individene. En slik fremgangsmåte gjør oss også i stand til å regne ut intraklasse korrelasjonskoeffisienter (ICC), som beskriver grad av sammenheng mellom svarene fra individer innenfor et og samme land (Snijders \& Bosker, 1999). Vi kjører i tillegg flernivåanalyser for å utforske sammenhengen mellom landspesifikke variabler og individenes oppfatning av familiens ansvar. Gitt at vi kun har data for tretten land, har disse analysene først og fremst et beskrivende formål.

\section{Resultater}

Figur 1 gir en første beskrivelse av hvor sterkt familiens ansvar står på tvers av Europa. Styrken er målt ved den samlete oppslutningen om de seks utsagnene om forpliktelser mellom voksne barn og eldre foreldre. Det hvite feltet i søylene (øverst) viser til andelene i de ulike landene som ikke er enige i noen av påstandene. Det sorte feltet (nederst) viser det motsatte, nemlig andelene som sier seg enige i alle seks. Grånyansene i mellom viser til enighet med henholdsvis 1-2 og 3-4 av påstandene. Jo mørkere søylene er, desto større er altså oppslutningen om familiens ansvar. 


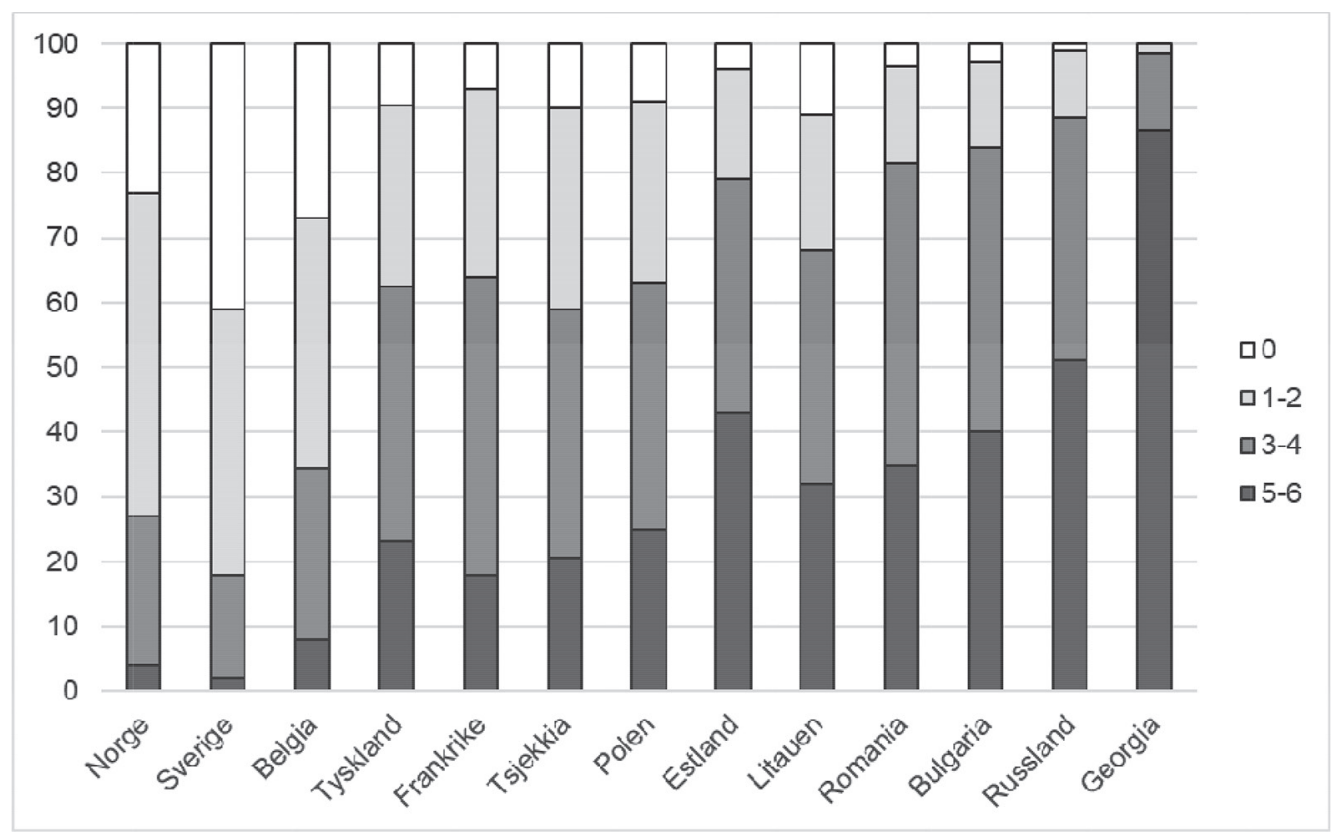

Figur 1. Oppslutning om familieforpliktelser. Andel enige (0-6) etter land (\%)

Det går tydelig fram av figuren at Georgia skiller seg ut med særlig høye andeler som er enige - her er det nær full oppslutning om familiens forpliktelser med 87 prosent som er enige i 5 eller 6 av påstandene og så godt som ingen $(0,2 \%)$ som ikke er enig i noen av dem. Norge, Sverige og Belgia skiller seg ut i motsatt retning. Her er det ytterst få som støtter forpliktelsene fullt ut (under $10 \%$ sier seg enige i 5-6 av påstandene) og forholdsvis mange som ikke er enige i noen av dem (omtrent $25 \%$ i Norge og Belgia og hele $40 \%$ i Sverige). Fordelingene iTyskland, Frankrike, Tsjekkia og Polen er tilnærmet like. Romania og Bulgaria likner også på hverandre, mens Russland ser ut til å befinne seg et sted mellom disse to landene og Georgia. Når det gjelder de to baltiske landene, utviser de litt forskjellige mønstre. Forpliktelsene i Estland står sterkere enn i Litauen og Estland likner dermed mest på Romania og Bulgaria, mens Litauen ser ut til å være likere Polen og Tsjekkia (figur 1). Dette kan virke noe overraskende, sett på bakgrunn av at Litauen er katolsk, mens Estland har en protestantisk tradisjon. Estland regnes dessuten som et av de mest sekulariserte landene i Europa (Plaat, 2003). Forklaringen har kanskje å giøre med den store russisk-språklige befolkningen i Estland som er overveiende ortodoks. I overkant av 25 prosent av det estiske utvalget er etnisk russiske (som også gjelder for befolkningen, se Statistics Estonia 2017) og mer inngående analyser viser at disse er gjennomgående mer positive til familiens ansvar enn etnisk estiske er. Andelen russiske i utvalget til Litauen er langt lavere (ca. $5 \%$, som er i overensstemmelse med fordelingen for landets befolkning, se Statistics Lithuania 2018).

Bildet som framgår av figuren bekreftes av gjennomsnittsskårene på den summerte familieansvarsindeksen for de ulike landene (se figur 2 og tabell i appendiks). 


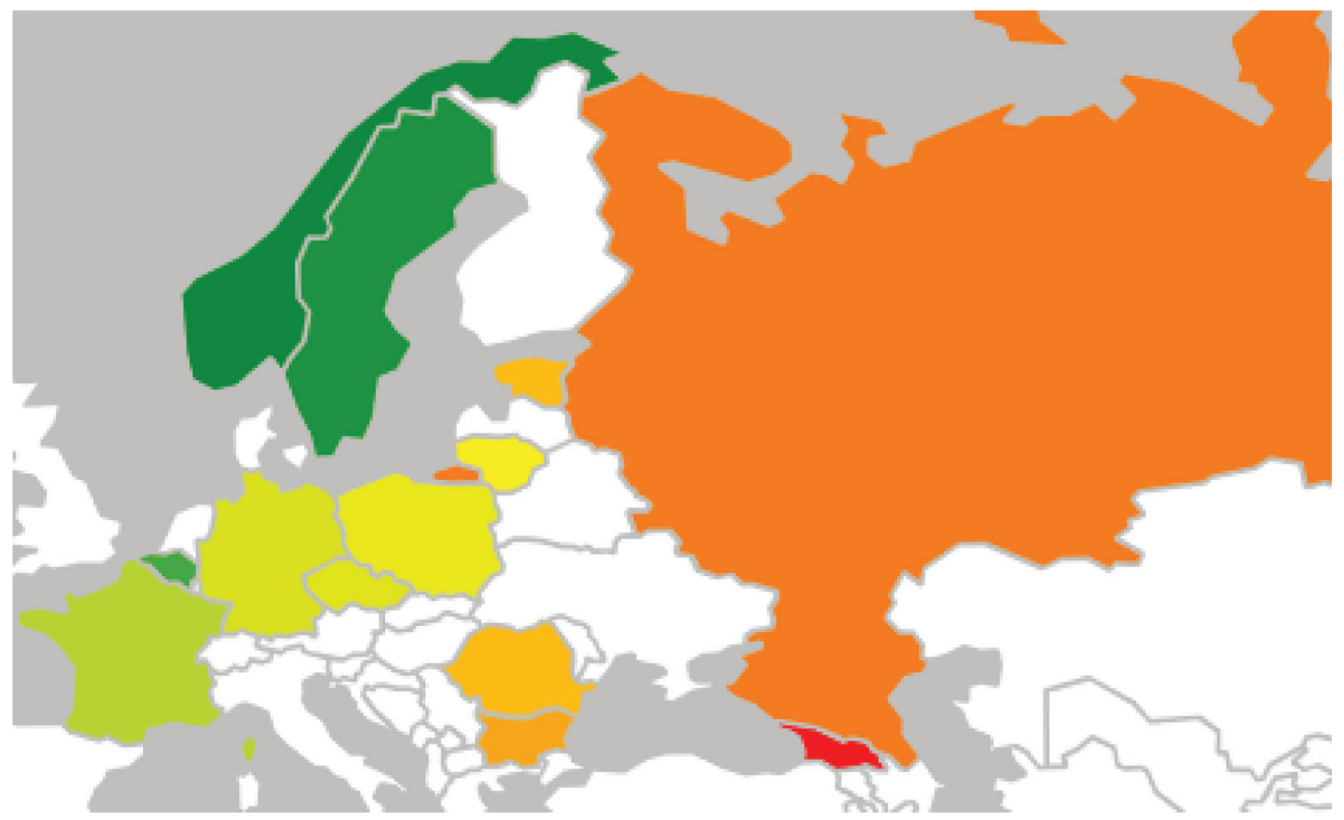

Figur 2. Oppslutning om familieforpliktelser. Koropletkart for gjennomsnittlig sumskåre etter land. Merknad: Jo grønnere farge, desto svakere, og jo rødere, desto sterkere er oppslutning om familieforpliktelser.

Jo grønnere farge på kartet, desto svakere - og jo rødere, desto sterkere står familiens ansvar. Norge og Sverige har de laveste gjennomsnittsskårene (henholdsvis 1,65 og 1,71) og landene er derfor tydelig grønnfargete (sammen med Belgia, 1,85). På den andre siden er Georgia som med en gjennomsnittsskåre på 3,2 er klart rød. Bortsett fra Estland og Romania, som har identiske skårer på 2,65, er forskjellene landene imellom statistisk signifikante ( $\mathrm{p}$ Tamhane $<0,001$, med unntak av Tyskland og Tsjekkia der $\mathrm{p}$ Tamhane < 0,004). Gjennomsnittskårene for Tsjekkia og Polen er likere skårene til Tyskland og Frankrike enn til skårene for Romania og Bulgaria (som også gjenspeiler resultatene vist i figur 1).

En flernivåanalyse med «random intercept» viser at den samlete variansen fordeler seg med 1,33 på landnivå og 2,53 på individnivå. Dette gir en intraklasse korrelasjonskoeffisient (ICC) på 0,35 , som betyr at hele 35 prosent av variasionen i holdninger til familieforpliktelser er knyttet til landtilhørighet. Det at mer enn en tredjedel handler om forskjeller mellom land, regnes som svært høyt, da det sjelden er mer enn 10-15 prosent av variansen som kan forklares av konteksttilhørighet (som region, land) (Pickett \& Pearl, 2001; Snijders \& Bosker, 1999). Det resterende 65 prosent dreier seg altså om forskjeller mellom individene i utvalget. Tidligere analyser har vist at egenskaper som spiller inn blant annet er kjønn, alder og utdanning, dog ikke nødvendigvis i samme retning i ulike land. Mens det for eksempel er en positiv sammenheng mellom utdanningsnivå og oppslutning om familienormer i Norge og Frankrike, er det motsatt i land som Romania, Bulgaria og Russland 
(Calzada \& Brooks, 2013; Daatland et al., 2011). Det kan dreie seg om forskjellige mekanismer i ulike land. Land som Norge og Frankrike har i større grad offentlige (og privat betalte) alternativer til eldreomsorg. For ressurssterke voksne barn kan det å si seg enig bety å sørge for at foreldre får den hjelpen de trenger, men uten at de nødvendigvis yter den selv. I land der det er få omsorgsalternativer, stiller det seg muligens annerledes da det å si seg enig vil kunne bety å måtte stille opp selv, noe høyt utdannete kan være mindre villige til da dette vil kunne komme i veien for en eventuell yrkeskarriere. Når det gjelder foreldreskap og holdninger til voksne barns ansvar derimot, ser tendensen ut til å være nokså lik på tvers av land - barnløse er mer positive enn foreldre. En forklaring kan kanskje være at foreldre ønsker å skåne egne barn fra en eventuell omsorgsbyrde (Daatland et al., 2011).

I figur 3 setter vi så de to settene av normer opp mot hverandre: voksne barns ansvar for eldre foreldre og foreldrenes ansvar for voksne barn. Det ene målet («filial responsibility») er basert på fire ledd, mens det andre ("parental responsibility») har to. For å kunne sammenlikne oppslutningen om ansvar oppover og nedover generasjonslinjen, viser vi her gjennomsnittsskårene for de to delindeksene (som begge varierer fra 0 til 4 ).

Ser vi på høyden til søylene i figur 3, går det frem at mønsteret - ikke overraskende - er omtrent det samme som vist i figur 1 og 2 . Georgia ligger høyest, mens Norge, Sverige og Belgia er lavest. Dette gjelder for oppslutningen om voksne barns ansvar så vel som for foreldres ansvar. Når det gjelder gjennomsnittsskåren til førstnevnte (barns ansvar), varierer den fra 1,5 i Norge til over 3,2 i Georgia. Dette er noe mer enn for foreldres ansvar, som varierer fra 1,8 (Belgia) til 3,2 (Georgia).

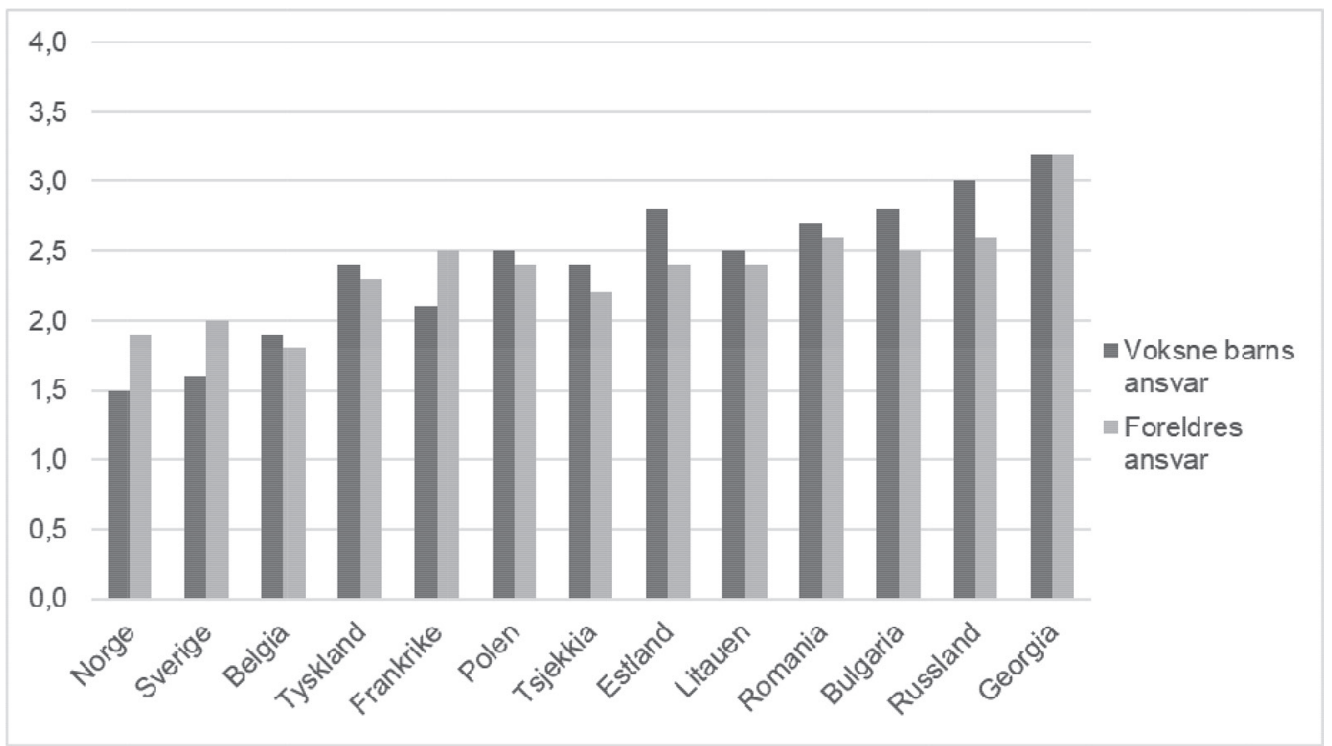

Figur 3. Oppslutning om voksne barns og foreldres forpliktelser overfor hverandre. Gjennomsnittlige sumskårer (0-4) etter land. 
Mer inngående flernivåanalyse med «random intercept» bekrefter at vesentlig mer av variasjonen for ansvaret oppover generasjonslinjen kan forklares på landnivå enn hva som er tilfellet for ansvaret nedover. For voksne barns ansvar kan 31 prosent forklares av kjennetegn ved landene, mens tilsvarende andel for foreldres ansvar er 16 prosent. Den resterende variasjonen dreier seg altså om forskjeller mellom individene.

Figur 3 illustrerer også karakteren til familienormene, nærmere bestemt om det er den eldre eller yngre generasjonen som ser ut til å prioriteres. Her er det interessante kontraster mellom landene. Ser vi bort fra Georgia, der oppslutningen er nesten universell uansett hvilken retning det er snakk om, så er gjennomsnittsskårene høyest for voksne barns ansvar i alle landene i det østlige Europa. Det samme gjelder for Belgia og Tyskland i vest, mens Norge, Sverige og Frankrike gir prioritet nedover - her er skårene for foreldres forpliktelser høyere enn for voksne barns ansvar. Det bør bemerkes at for flere land (Belgia, Tyskland, Polen, Litauen og Romania) er forskjellene svært små $(0,1)$. For Norge, Sverige og Frankrike derimot, som gir prioritet nedover generasjonslinjen, er forskjellene relativt større $(0,4)$.

Hvordan svarene fordeler seg på de ulike leddene, er vist i tabellen i appendikset. Vi vil her bare kort kommentere noen av resultatene. Det er relativt bred enighet i det østlige Europa (unntatt Tsjekkia) om at voksne barn bør ha foreldre boende hos seg når foreldre ikke lenger kan klare seg selv - fra 60 prosent i Polen til hele 91 prosent i Georgia. Tsjekkia (47 \%) likner her mer på Tyskland og Frankrike med henholdsvis 44 og 42 prosent enige. Norge og Sverige derimot, ligger vesentlig lavere med $5 \mathrm{og} 10$ prosent. Befolkningen i de to nordiske landene er mer åpen for at voksne barn har ansvar for å gi omsorg når foreldre trenger det (49 og $36 \%$ enige), men andelen enige er også for dette spørsmålet langt lavere enn i øst, der nærmere 80 prosent eller flere sier seg enige. I Georgia slutter så godt som alle (99\%) opp om en slik forpliktelse. Det er også her store likheter mellom Tyskland og Tsjekkia (78-79 \%). Når det gjelder ansvaret den andre veien, er det en drøy tredjedel i Norge og Sverige som er enige i at foreldre bør gi finansiell støtte til voksne barn med økonomiske vansker. Andelene i øst varierer fra nærmere 50 til 96 prosent. Her ligger imidlertid Tyskland (67\%) og Frankrike (76 \%) høyere enn flere av landene i øst. Hvorvidt foreldre bør tilpasse jobben etter voksne barns behov, har derimot et klarere øst-vest skille med høyere andeler enige $i$ alle landene $i ø s t$ enn $i$ vest med unntak av Tsjekkia (35\%), som her ligger litt lavere enn Frankrike (37 \%). I Norge og Sverige oppgir 18-19 prosent at de er enige, sammenliknet med 87 prosent i Georgia.

Som nevnt over, kan en god del av variasjonen i oppslutningen om familieforpliktelser forklares ved karakteristika ved de ulike landene. Figur $4 \mathrm{a}-\mathrm{d}$ viser sammenhengen mellom familieansvarsskårer (gjennomsnittlige sumskårer) og utvalgte kjennetegn ved landene (hentet fra oversikten over kontekstuelle data i tabell 1). Både kjøpekraftkorrigert bruttonasjonalprodukt per innbygger, helseutgifter (som andel av BNP) og institusjonsrater (for befolkningen 65 år og eldre) og forventet 

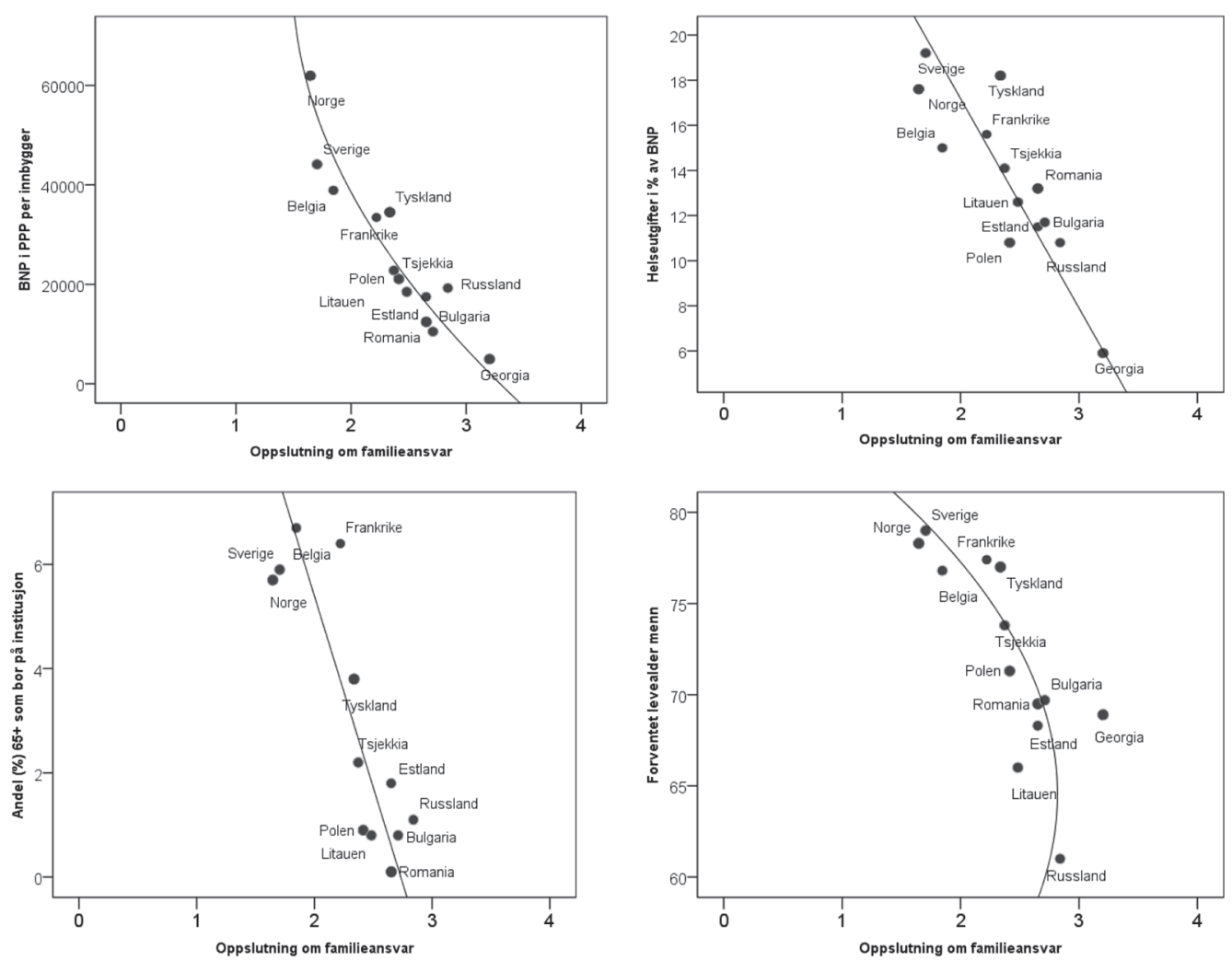

Figur $4 a-d$. Sammenhenger mellom ulike landkjennetegn og oppslutning om familiens ansvar.

levealder (her vist for menn) korrelerer sterkt med familieansvar (>0.70). Når det gjelder kjøpekraftskorrigert bruttonasjonalprodukt (BNP i PPP per innbygger), ser sammenhengen ut til å være kurvelineær (figur 4a). Jo høyere verdi et land har, desto lavere er oppslutningen om familiens ansvar. Sammenhengen flater imidlertid ut for høyere verdier, i dette tilfelle $>38000$ USD (per innbygger). For helseutgifter (som andel av BNP) og familieansvar (figur 4b) er sammenhengen tilnærmet lineær: jo høyere helseutgifter $\mathrm{i}$ et land, desto lavere er oppslutningen. Videre viser figur 4c at det er forholdsvis lavere oppslutning $\mathrm{i}$ land som har en større andel personer $\mathrm{i}$ alderen 65 år og eldre boende på institusjon enn i land der institusjonsraten er lav. Som en indikasjon på befolkningens helsetilstand, har vi til sist tatt med forventet levealder (for menn). Figur $4 \mathrm{~d}$ viser at jo høyere forventet levealder for menn, desto lavere er oppslutningen om familieansvar. Sammenhengen flater imidlertid noe ut når forventet levealder er lavere enn 70 år. Hvert av disse fire kjennetegnene ved land forklarer mellom 46 prosent (forventet levealder) og 68 prosent (BNP i PPP per innbygger) av den opprinnelige variasjonen mellom de tretten landene. Med et såpass begrenset antall land har imidlertid den forklarte variasjonen først og fremst et beskrivende formål og bør tolkes med varsomhet. 


\section{Diskusjon og avslutning}

Hvorvidt det gir mening å kategorisere land etter familietyper, er det delte meninger om. Stołtysek (2012) er kritisk til ideen om et øst-vest skille som han hevder i hovedsak har blitt presentert av vestlige forskere. Argumentasjonen hans er at det er stor variasjon innad i det østlige Europa som overses i slike forenklete fremstillinger. Viazzo (2010) derimot, har gjennomgått en rekke studier av dagens familie- og slektsstrukturer, og gir støtte til Reher (1998) i sin konklusjon om at det fortsatt er betydelige forskjeller i familiekultur mellom ulike deler av Europa.

I denne artikkelen har vi belyst det normbaserte aspektet ved familierelasjoner, nærmere bestemt holdninger til familiens ansvar overfor eldre og yngre generasjoner. Alt i alt viser resultatene at forpliktelsene står sterkere i øst enn i vest. Landene som er med $\mathrm{i}$ våre analyser ser ut til å fordele seg nokså nær den geografiske diagonalen mellom det nord-vestlige og sør-østlige Europa. Det er noe uklart hvor øst-vest skillet går, men det ser ut til å gå lengre øst enn den såkalte «Hajnal-linjen». Både Polen og Tsjekkia likner mer på Tyskland og Frankrike enn på de øvrige landene i det østlige Europa. Litauen fremstår som likere Polen enn Estland, mens Estland likner mer på Romania og Bulgaria. Ser vi på karakteren til familienormene, nærmere bestemt om det er den yngre eller den eldre generasjonen som prioriteres, er det ikke noe klart øst-vest skille. Mens Norge, Sverige og Frankrike gir prioritet nedover generasjonslinjen, er det motsatte tilfellet for Belgia og Tyskland. Mønsteret i de to sistnevnte landene likner dermed på det østlige Europa, med unntak av Georgia som prioriterer de to generasjonene likt.

Kontrastene er særlig store mellom ytterpunktene - Norge og Sverige i nordvest og Georgia i sørøst. I Skandinavia står idealet om uavhengighet mellom generasjonene sterkt. Voksne familiemedlemmer bør ha muligheter for å leve sine egne liv, men være tilgjengelige for hverandre dersom situasjonen (behovene) krever det, dog innenfor bestemte (rimelige) grenser. Svært få i Norge og Sverige er enige i alle de seks påstandene om familiens ansvar, mens en relativt stor andel oppgir at de er uenige. Det kan de også tillate seg å være. Befolkningen i disse to landene er ikke prisgitt familien ettersom det finnes offentlige alternativer. Det betyr ikke at voksne barn og foreldre ikke stiller opp for hverandre. Konklusjonen til Daatland og Herlofson (2004) er at familien og velferdsstaten er komplementære. Dette kommer også frem i beregninger fra Statistisk sentralbyrå som viser at omkring 40 prosent av eldreomsorgen i Norge utføres av pårørende (Holmøy, Haugstveit \& Otnes, 2016).

I Georgia er nær alle enige $i$ at voksne barn bør ta omsorg for eldre foreldre og at foreldre bør hjelpe sine voksne barn økonomisk. Her ser det altså ut til å være plikten som rår, trolig fordi det ikke finnes mange alternativer å støtte seg på enn familien. Landet hadde en ledende posisjon økonomisk sett da det var del av Sovjetunionen, men opplevde en betydelig nedgang i årene etter løsrivelsen (Zubiashvili \& Silagadze, 2016). I en studie fra midten av 1990-tallet oppga hele 20 prosent at de hadde problemer med å dekke husholdets behov for mat. Kun én prosent svarte at de hadde nok til at de kunne hjelpe familie og venner (Dersheim \& Gzirishvili, 1998). I 
følge Baumann (2012, s. 259) har landet fortsatt "en lang, lang vei igjen til 'moderne' sosial beskyttelse». Så mens skandinaver har tilgang til offentlige tjenester som dekker både omsorg og eventuelle økonomiske behov, så har befolkningen i Georgia få alternativer til familiehjelp. Da er det kanskje ikke annet å vente enn at normer knyttet til familiens ansvar får nærmest full oppslutning i befolkningen. Retningen på sammenhengen kan imidlertid gå begge veier. Dersom det er en inngrodd norm at familiegenerasjonene tar seg av hverandre, vil det kanskje heller ikke være samme behov for utvikling av formelle tjenester.

Reher (1998) la vekt på ulikheter i familiekultur som forklaring på familiebåndenes styrke. Han baserte i hovedsak sine konklusjoner på omfanget av flergenerasjonshushold og familieomsorg til eldre. Hvorvidt denne type indikatorer handler om sterke eller svake familier eller om det snarere dreier seg om ulik tilgang til alternativer, kan diskuteres. Kulturen (idealene) kan nok ha en god del å si, men like viktig, eller kanskje viktigere, er de strukturelle rammebetingelsene (mulighetene). De to faktorene henger imidlertid gjerne sammen og kan dra i samme retning - noe som giør det vanskelig å skille den ene forklaringen fra den andre.

Familierelasjoner har mange aspekter.Vi har her tatt for oss en av dem, den normative dimensjonen. Inkludering av øvrige sider ved forholdet kan gi andre bilder av familiens styrke og karakter. Hvilke og hvor mange land som inkluderes, har også betydning. Utvidelsen til tretten land i denne studien har gjort variasjonen større og øst-vest skillet mindre tydelig enn det som har blitt vist i tidligere forskning med mindre utvalg (Daatland et al., 2011; Mureşan \& Hărăguş, 2015). Muligens holder det ikke med Hajnals (1965) to-deling da det kan være vanskelig å plassere landene i det sentrale Europa i den ene eller andre delen. Hvordan bildet ville sett ut hvis vi også hadde hatt data fra Sør-Europa, kan vi bare spekulere i.

Mønstre kan endre seg over tid. Kanskje vil en eventuell utvikling i retning av en større utjevning av forskjeller landene imellom, både når det gjelder tilbud av helse- og omsorgstjenester, økonomiske støtteordninger og familiens omsorgsansvar, kunne resultere $i$ en viss konvergens i befolkningens holdninger til familiens ansvar. Viazzo (2010) tenker seg at det i så fall vil være befolkningen i de mer sjenerøse velferdsstatene i nordvest som vil nærme seg landene i sør og øst. Selv er vi nok mer tilbøyelige til å anta at sannsynligheten for det motsatte er større, da vi har vanskelig for å tro at mer tradisjonelle familienormer og former vil få økt oppslutning $i$ årene fremover i den nordlige og vestlige delen av Europa.

\section{Om artikkelen}

Artikkelen er skrevet med finansiering fra Norges forskningsråd (prosjektnr. 236997). 


\section{Referanser}

Baumann, E. (2012). Post-Soviet Georgia: It's a long, long way to "modern" social protection... Economies et Sociétés 46 (2), s. 259-85.

Bengtson, V. L. \& Putney, N. M. (2000). Who will care for tomorrow's elderly? Consequences of population aging in east and west. IV. L. Bengtson et al. (Red.), Aging in East and West. Families, states and the elderly (s. 263-86). New York: Springer Publishing Company.

Bengtson, V. L. \& Roberts, R. E. L. (1991). Intergenerational solidarity in aging families: An example of formal theory construction. Fournal of Marriage and the Family 53 (4), s. 856-70.

Billari, F. \& Liefbroer, A. C. (2010). Towards a new pattern of transition to adulthood? Advances in Life Course Research 15 (2-3), s. 59-75.

Billingsley, S. (2010). The post-communism puzzle. Population Research and Policy Review 29 (2), s. $193-231$.

Blustein, J. (1997). Procreation and parental responsibility. Fournal of Social Philosophy 28 (2), s. 79-86.

Brandt, M., Haberkern, K. \& Szydlik. M. (2009). Intergenerational help and care in Europe. European Sociological Review 25 (5), s. 585-601.

Calzada, I. \& Brooks, C. (2013). The myth of Mediterranean familism. Family values, family structure and public preferences for state intervention in care. European Societies 15 (4), s. 514-34.

Castiglioni, M., Hărăguş, M., Faludi, C. \& Hărăguş, P. T. (2016). Is the family system in Romania similar to those of Southern European countries? Comparative Population Studies - Zeitschrift für Bevölkerungswissenschaft 41 (1), s. 57-86.

Dersheim, L. \& Gzirishvili, D. (1998). Informal social support networks and household vulnerability: Empirical findings from Georgia. World Development 26 (10), s. 1827-38.

Dykstra, P. (2018). Cross-national differences in intergenerational family relations: The influence of public policy arrangements. Innovation in Aging. Hentet fra https://doi.org/10.1093/geroni/igx032.

Daatland, S. O. \& Herlofson, K. (2004). Familie, velferdsstat og aldring. NOVA rapport 7/04. Oslo: NOVA.

Daatland, S. O. \& Lowenstein, A. (2005). Intergenerational solidarity and the family-welfare state balance. European fournal of Ageing 2 (3), s. 174-82.

Daatland, S. O., Herlofson, K. \& Lima, I. A. (2011). Balancing generations: On the strength and character of family norms in the west and east of Europe. Ageing and Society, 31 (7), s. 1159-79.

Esping-Andersen, G. (1999). Social Foundations of Postindustrial Economies. Oxford: Oxford University Press.

Finley, N., Roberts, M. D. \& Banahan, B. F. (1988). Motivators and inhibitors of attitudes of filial obligation toward aging parents. The Gerontologist 28 (1), s. 73-78.

Fokkema, T., Emery, T., Kveder, A., Liefbroer, A. C. \& Hiekel, N. (2016). Generations and Gender Programme Wave 1 data collection: An overview and assessment of sampling and fieldwork methods, weighting procedures, and cross-sectional representativeness. Demographic Research 34, s. 499-524.

Gaunt, D. (1983). Familjeliv $i$ Norden. Södertälje: Gidlunds Förlag.

Ghodsee, K. \& Bernardi, L. (2012). Starting a family at your parents' house: Multigenerational households and below replacement fertility in urban Bulgaria. Fournal of Comparative Family Studies 43 (3), s. 439-59.

Greeley, A. (1989). Protestant and Catholic: Is the analogical imagination extinct? American Sociological Review 54 (4), s. 485-502.

Gutmann, D. (1987). Reclaimed powers:Towards a new psychology of men and women in late life. New York: Basic Books.

Hagestad, G. O. (2003). Interdependent lives and relationships in changing times: A life-course view of families and aging. I R. A. Settersten (Red.), Invitation to the life course. Towards a new understanding of later life (s. 135-59). Amityville: Baywood Publishing Company.

Hajnal, J. (1965). European marriage patterns in perspective. I D.V. Glass \& D. E. C. Eversley (Red.), Population in history. Essays in historical demography (s. 101-43). London: Edward Arnold.

Hank, K. (2007). Proximity and contacts between older parents and their children: A European comparison. fournal of Marriage and Family 69 (1), s. 157-73.

Herring, J. (2008). Together forever. The rights and responsibilities of adult children and their parents. I J. Bridgeman, H. Keating \& C. Lind (Red.), Responsibility, law and the family (s. 41-62). London: Routledge.

Holmøy, E., Haugstveit, F. V., \& Otnes, B. (2016). Behovet for arbeidskraft og omsorgsboliger $i$ pleie- og omsorgssektoren mot 2060. Rapporter 2016/20. Oslo: Statistisk sentralbyrå.

Höllinger, F. \& Haller, M. (1990). Kinship and social networks in modern societies: A cross-cultural comparison among seven nations. European Sociological Review 6 (2), s. 103-24.

Iacovu, M. \& Skew, A. J. (2011). Household composition across the new Europe: where do the new Member States fit in? Demographic Research 25, s. 465-89. 
Ikels, C. (2004). Introduction. I C. Ikels (Red.), Filial piety: Practice and discourse in contemporary East Asia (s. 1-15). Stanford: Stanford University Press.

Laslett, P. (1983). Family and household as work group and kin group: Areas of traditional Europe compared. I R. Wall (Red.), Family forms in historic Europe (s. 513-63). Cambridge: Cambridge University Press.

Lee, G. R., Peek, C. W. \& Coward, R. T. (1998). Race differences in filial responsibility expectations among older parents. Fournal of Marriage and the Family 60 (2), s. 404-12.

Li, W. W. (2011). Filial piety, parental piety and community piety: Changing cultural practices of elder support among Chinese migrant families in New Zealand. OMNES: The fournal of Multicultural Society 2 (1), s. 1-30.

Lowenstein, A. \& Daatland, S. O. (2006). Filial norms and family support in a comparative cross-national context: Evidence from the OASIS study. Ageing $\mathcal{G}$ Society 26 (2), s. 203-23.

Marckmann, B. (2017). All is not relative: Intergenerational norms in Europe. European Societies 19 (4), s. $466-91$.

Mureşan, C. \& Hărăguş, P.-T. (2015). Norms of filial obligation and actual support to parents in Central and Eastern Europe. Romanian fournal of Population Studies 9 (2), s. 49-81.

Murphy, M. (2008). Variations in kinship networks across geographic and social space. Population and Development Review 34 (1), s. 19-49.

Mönkediek, B. \& Bras, H. (2014). Strong and weak family ties revisited: Reconsidering European family structures from a network perspectiv. The History of Family 19 (2), s. 235-59.

Pickett, K. E. \& Pearl, M. (2001). Multilevel analyses of neighbourhood socioeconomic context and health outcomes: A critical review. Fournal of Epidemiology E Community Health 55 (2), s. 111-22.

Plaat, J. (2003). Religious change in Estonia and the Baltic states during the Soviet period in comparative perspective. Fournal of Baltic Studies 34 (1), s. 52-73.

Preoteasa, A. M., Vlase, I. \& Tufã, L. A. (2018). Intergenerational support as a reaction to socio-economic crisis: Alteration of solidarity within precarious Romanian households. European Societies 20 (1), s. $111-30$.

Pruchno, R. A. \& Smyer, M. A. (2007). Introduction: The science and ethics of aging well. I R. A. Pruchno \& M. A. Smyer (Red.), The challenges of an aging society. Ethical dilemmas, political issues (s. 1-16). Baltimore: Johns Hopkins University Press.

Rajkai, Z. (2015). Introduction. I Z. Rajkai (Red.), Family and social change in socialist and post-socialist societies. Change and continuity in Eastern Europe and East Asia. (s. 1-18). Leiden: Brill.

Reher, D. S. (1998). Family ties in Western Europe: Persistent contrasts. Population and Development Review 24 (2), s. 203-34.

Robila, M. (2004). Families in Eastern Europe: Context, trends and variations. Contemporary Perspectives in Family Research 5, s. 1-14.

Saraceno, C. \& Keck, W. (2008). The institutional framework of intergenerational family obligations in Europe: A conceptual and methodological overview. Hentet fra http:/www.multilinks-project.eu/wp-content/uploads/ 2009/04/ Report_Saraceno_Keck_Nov081.pdf

Slagsvold, B., Veenstra, M., Daatland, S. O. et al. (2012). Life-course, ageing and generations in Norway: The NorLAG study. Norsk Epidemiologi 22, s. 95-102.

Snijders, T. \& Bosker, R. (1999). Multilevel Analysis. An introduction to basic and advanced multilevel modeling. London: Sage Publications.

Sobotka, T. (2008). The diverse faces of the Second Demographic Transition in Europe. Demographic Research 19 , s. $171-224$.

Sobotka, T. (2011). Fertility in Central and Eastern Europe after 1989: Collapse and gradual recovery. Historical Social Research 36 (2), s. 246-96.

Sogner, S. \& Telste, K. (2005). Ut å søkje teneste - historia om tenestejentene. Oslo: Samlaget.

Sotiropoulos, D. A., Neamtu, I. \& Stovanova, M. (2003). The trajectory of post-communist welfare state development: The cases of Bulgaria and Romania. Social Policy E Administration 37 (6), s. 656-73.

Statistics Estonia (2017). RV0222 Population by sex, ethnic nationality and county, 1 January 2017. http:// andmebaas.stat.ee/

Statistics Lithuania (2018). Proportion of the population by ethnicity, compared to the total resident population. Offical Statistics Portal, https:/osp.stat.gov.lt/en_GB/

Stołtysek, M. (2012). Spatial construction of European family and household systems: A promising path or a blind alley? An Eastern European perspective. Continuity and change 27 (1), s. 11-52.

Sung, K.-T. (1990). A new look at filial piety: Ideals and practices of family-centered parent care in Korea. The Gerontologist 30 (5), s. 610-17. 


\section{HERLOFSON, DAATLAND \& VEENSTRA}

Szydlik, M. (1996). Parent-child relations in East andWest Germany shortly after the fall of the wall. International fournal of Sociology and Social Policy 16 (12), s. 63-88.

Tarum, H. \& Kutsar, D. (2018). Compulsory intergenerational family solidarity shaping choices between work and care: Perceptions of informal female carers and local policymakers in Estonia. International fournal of Social Welfare 27 (1), s. 40-51.

Treas, J. \& Wang, W. (1993). Of deeds and contracts. Filial piety perceived in contemporary Shanghai. I V. L. Bengtson \& W. A. Achenbaum (Red.), The changing contract across generations (s. 87-98). New York: Aldine de Gruyter.

Van den Akker, P., Halman, L. \& de Moor, R. (1998). Primary relations in Western Europe. I P. Ester, L. Halman \& R. de Moor (Red.), The individualizing society. Value change in Europe and North America (s. 97-127). Tilburg: Tilburg University Press.

Verbakel, E. (2018). How to understand informal caregiving in Europe? The role of formal long-term care provision and family care norms. Scandinavian fournal of Public Health 46 (4), s. 436-47.

Viazzo, P. P. (2010). Family, kinship and welfare provision in Europe, past and present: Commonalities and divergences. Continuity and change 25 (1), s. 137-59.

Zimmer, Z., Rada, C., \& Stoica, C. A. (2014). Migration, location and provision of support to older parents: The case of Romania. Population Ageing 7 (3), s. 161-84.

Zubiashvili, T. \& Silagadze, L. (2016). Some aspects of the Georgian economy at the contemporary stage. Ecoforum 5 (29), s. 70-3. 


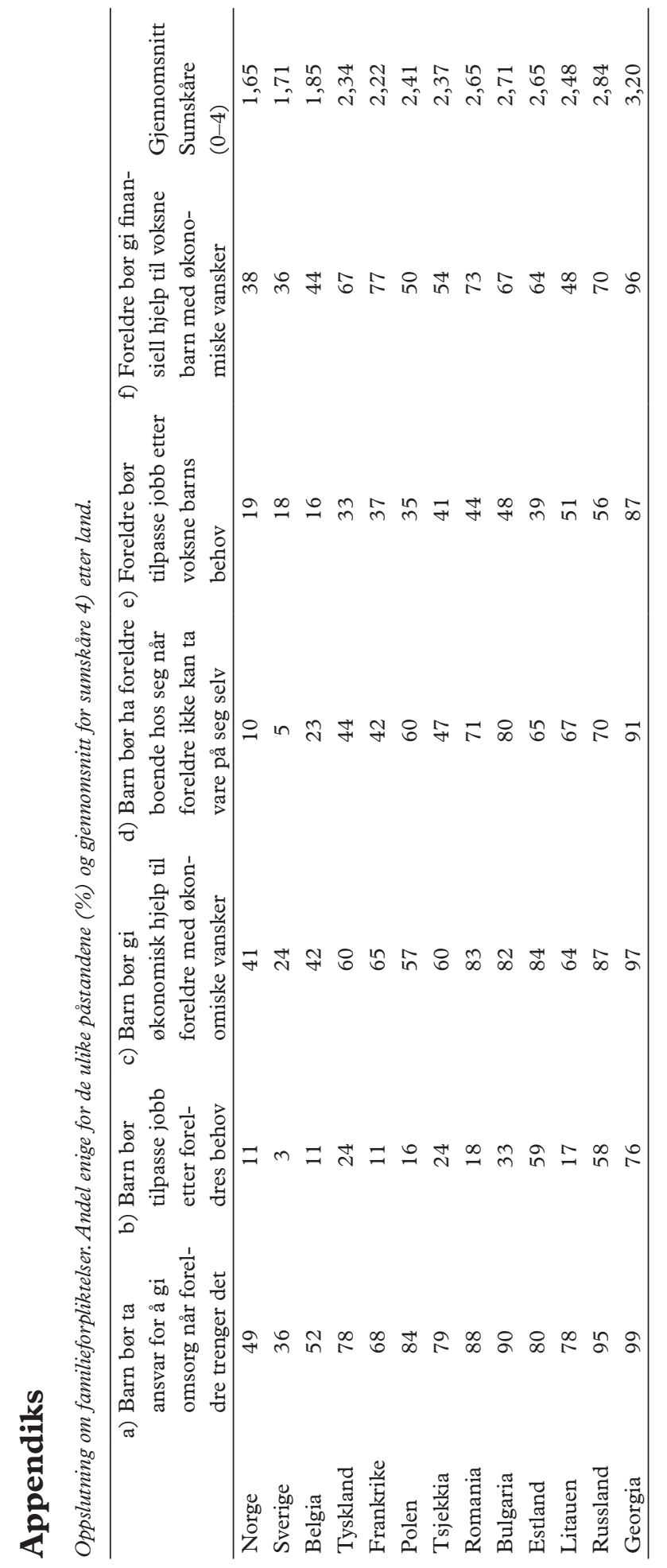

